\title{
Aggressive and Malignant Prolactinomas
}

\author{
Nicoleta Cristina Olarescu ${ }^{a}$ Luis G. Perez-Rivas ${ }^{b}$ Federico Gatto ${ }^{c}$ \\ Thomas Cuny $^{d}$ Maria A. Tichomirowa ${ }^{e}$ Gianluca Tamagno ${ }^{f, g}$ \\ Manuel D. Gahete ${ }^{h-k}$ on behalf of EYRC (ENEA Young Researcher Committee)
}

\begin{abstract}
a Section of Specialized Endocrinology, Department of Endocrinology, Oslo University Hospital, Oslo, Norway;
${ }^{\mathrm{b}}$ Medizinische Klinik und Poliklinik IV, Klinikum der LMU, Ludwig-Maximilians-Universität München, Munich, Germany; 'Endocrinology Unit, IRCCS Ospedale Policlinico San Martino, Genoa, Italy; ${ }^{d}$ Service d'Endocrinologie, Hôpital de la Conception, Inserm U1251, Marseille Medical Genetics, APHM, Aix-Marseille University, Marseille, France; ${ }^{e}$ Service d'Endocrinologie, Centre Hospitalier du Nord, Ettelbruck, Luxembourg; ${ }^{f}$ Department of Endocrinology/Diabetes Mellitus, Mater Misericordiae University Hospital, Dublin, Ireland; 9 Department of Medicine, Wexford General Hospital, Wexford, Ireland; ${ }^{\mathrm{h}}$ Maimonides Institute for Biomedical Research of Cordoba (IMIBIC), Cordoba, Spain; 'Universidad de Córdoba, Cordoba, Spain; ${ }^{\mathrm{i}}$ Reina Sofia University Hospital, Cordoba, Spain; kCIBER Fisiopatología de la Obesidad y Nutrición (CIBERobn), Cordoba, Spain
\end{abstract}

\section{Keywords}

Aggressiveness · Dopamine receptor · Dopamine agonists · Preclinical models

\begin{abstract}
Prolactin-secreting tumors (prolactinomas) represent the most common pituitary tumor type, accounting for $47-66 \%$ of functional pituitary tumors. Prolactinomas are usually benign and controllable tumors as they express abundant levels of dopamine type 2 receptor (D2), and can be treated with dopaminergic drugs, effectively reducing prolactin levels and tumor volume. However, a proportion of prolactinomas exhibit aggressive features (including invasiveness, relevant growth despite adequate dopamine agonist treatment, and recurrence potential) and few may exhibit metastasizing potential (carcinomas). In this context, the clinical, pathological, and molecular definitions of malignant and aggressive prolactinomas remain to be clearly defined, as primary prolactin-secreting carcinomas are similar to aggressive adenomas until the presence of metasta-
\end{abstract}

\section{KARGER}

(C) 2019 S. Karger AG, Basel

E-Mail karger@karger.com

www.karger.com/nen ses is detected. Indeed, standard molecular and histological analyses do not reflect differences between carcinomas and adenomas at a first glance and have limitations in prediction of the aggressive progression of prolactinomas, wherein the causes underlying the aggressive behavior remain unknown. Herein we present a comprehensive, multidisciplinary review of the most relevant epidemiological, clinical, pathological, genetic, biochemical, and molecular aspects of aggressive and malignant prolactinomas.

(c) 2019 S. Karger AG, Basel

\section{Introduction}

Prolactin (PRL)-secreting tumors or prolactinomas comprise the most common pituitary tumor type, accounting for $47-66 \%$ of all pituitary tumors $[1,2]$. Prolac-

Manuel D. Gahete

Ed. IMIBIC. Avda. Menéndez Pidal s/n

ES-14004 Cordoba (Spain)

E-Mail bc2gaorm@uco.es

Nicoleta C. Olarescu

Department of Specialized Endocrinology Oslo University Hospital, Rikshospitalet

Box 4950, Nydalen, NO-0424 Oslo (Norway)

E-Mail nicola@rr-research.no 
tinomas are inexorably associated with hyperprolactinemia, which results in impaired fertility, decreased libido, amenorrhea, and galactorrhea. However, tumor growth also leads to compressive mass effects, resulting in headache, visual disturbances, and hypopituitarism [3]. Prolactinomas, like other pituitary tumor types, are categorized by the World Health Organization 2017 classification into PRL-producing adenomas and carcinomas [4]. PRL-producing pituitary adenomas are classified as microadenomas (which are smaller than $10 \mathrm{~mm}$ in diameter), macroadenomas (which are equal to or larger than $10 \mathrm{~mm}$ ), and giant prolactinomas (characterized by a tumor size larger than $40 \mathrm{~mm}$ ) [3]. PRL-producing pituitary carcinomas are defined by the presence of cerebrospinal, meningeal, or distant metastasis [4]. From a clinical perspective, in contrast to other pituitary tumors, prolactinomas respond well to medical therapy alone as first-line treatment. Due to the abundant expression of dopamine type 2 receptor (D2), these tumors can be treated with dopaminergic drugs (mainly bromocriptine and cabergoline), which effectively reduce PRL levels and decrease the tumor volume in most cases [3].

Pituitary tumors are highly heterogeneous lesions and, despite being considered benign, many of them are invasive $(30-45 \%)[5,6]$, with up to $15 \%$ being clinically aggressive $[7,8]$. For this reason, a new terminology, i.e., pituitary neuroendocrine tumors or PitNETs, has been recently proposed in order to highlight the complex and heterogeneous features of these neoplasms [9]. In this sense, the European Society of Endocrinology (ESE) recently published clinical practice guidelines for the management of these forms of pituitary lesions, including aggressive pituitary tumors and carcinomas. In particular, in the guidelines, aggressiveness is defined as a radiologically invasive tumor with an unusually rapid tumor growth rate, or clinically relevant tumor growth despite optimal standard therapies (surgery, radiotherapy, and conventional medical treatments), while carcinoma is defined as a tumor that metastasizes [10]. Truly pituitary carcinomas are very rare and, from a clinically relevant perspective, the concept of aggressiveness in prolactinomas should include, in addition to these rare cases of PRL-secreting carcinomas with metastasis, also the cases of locally invasive prolactinomas, including giant prolactinomas, that show a rapid tumor growth and are resistant to treatment with dopamine agonists (DA) [11]. Such an extended concept may embrace the biological, pathological, anatomical, and clinical aspects which may be hallmarks of aggressiveness in endocrine diseases. Prolactinomas associated with neuroendocrine syndromes
Table 1. Main characteristics of aggressive prolactinomas

\begin{tabular}{|c|c|}
\hline Characteristic & Description \\
\hline $\begin{array}{l}\text { Clinical } \\
\text { features }\end{array}$ & $\begin{array}{l}\text { Radiologically invasive tumors that are resistant } \\
\text { to optimal DA therapy and show recurrence } \\
\text { potential after surgery and/or radiotherapy } \\
\text { (adapted from Raverot et al. [10]) }\end{array}$ \\
\hline $\begin{array}{l}\text { Medical } \\
\text { management }\end{array}$ & $\begin{array}{l}\text { TMZ [45] } \\
\text { Lapatinib and cabergoline [62] } \\
\text { Pasireotide long-acting release [51] } \\
\text { Everolimus [44] }\end{array}$ \\
\hline $\begin{array}{l}\text { Nonmedical } \\
\text { management }\end{array}$ & $\begin{array}{l}\text { Surgery [66] } \\
\text { Radiotherapy [69] } \\
\text { PRRT [75] }\end{array}$ \\
\hline $\begin{array}{l}\text { Pathology } \\
\text { markers }\end{array}$ & $\begin{array}{l}2 \text { out of } 3 \text { proliferative markers }(\mathrm{Ki}-67 \text { index }>3 \% \\
\text { in formalin fixative, mitoses }>2 / 10 \mathrm{HPF} \text {, positive } \\
\text { p53 [10 strongly positive nuclei/10 HPF]) [10] }\end{array}$ \\
\hline $\begin{array}{l}\text { Molecular } \\
\text { markers }\end{array}$ & $\begin{array}{l}\text { Decrease in DRD2 mRNA transcription and/or } \\
\text { alterations in the D2 receptor-related signaling } \\
\text { pathways [33-35] } \\
\text { DRD2 gene splicing variants and polymorphisms } \\
\text { [36-38] } \\
\text { Lower levels of PRDM2, Filamin A, or PRB3 } \\
{[39,40]} \\
\text { Elevated TGF- } \beta_{1} / \text { Smad3 signaling pathway [41] } \\
\text { High levels of ADAMTS6, ASK, CCNB1, CENPE, } \\
\text { CRMP1, and ALK7 mRNA (determined by } \\
\text { qPCR) }[10,92,95]\end{array}$ \\
\hline
\end{tabular}

$\mathrm{HPF}$, high-power fields at $\times 400$ magnification; $D R D 2$, type 2 dopamine receptor gene; D2, type 2 dopamine receptor; PRDM2, PR domain zinc finger protein 2 .

are also discussed, since some of them pose some difficulties in terms of their management [11].

Radiation therapy and temozolomide (TMZ), an oral alkylating agent, are useful adjuvant therapies in cases where an aggressive prolactinoma cannot be controlled despite the optimal conventional medical treatment and surgery $[12,13]$; however, the efficacy of such approaches is variable and significant side effects or complications may arise $[14,15]$. Due to the complex and multimodal management required, patients with aggressive prolactinomas should be referred to tertiary centers for multidisciplinary treatment [10].

In particular, we review herein the current state of the art of the clinical approach to and the management of malignant and aggressive (invasive/giant and resistant to treatment) prolactinomas, including an insight on the
Olarescu/Perez-Rivas/Gatto/Cuny/ Tichomirowa/Tamagno/Gahete/ 
most relevant pathologic diagnosis and treatment aspects (Table 1).

\section{Clinical and Medical Aspects}

\section{Malignant Prolactinomas}

PRL-secreting carcinomas are very rare and their diagnostic definition is usually challenging. Although the exact incidence is not well established, pituitary carcinomas represent $0.2 \%$ of all operated adenohypophyseal tumors [16]. Indeed, the most common types of pituitary tumors that progress to carcinoma are prolactinomas and $\mathrm{ACTH}$ positive adenomas [17]. Initially, malignant prolactinomas are indistinguishable from aggressive adenomas and there is no biomarker that can reliably predict malignancy as defined by the metastatic spread [9]. A combination of clinical and histological features seems to be required for the diagnosis of malignant prolactinomas, including the evolution of the tumor over time and the assessment of proliferation markers [18, 19], but they are neither sufficient to distinguish between carcinomas and adenomas nor able to predict whether and why the aggressive tumor will become cancerous and metastasize. In fact, only after the evidence of cerebrospinal and/or systemic metastases has been obtained can the diagnosis of carcinoma be confirmed [20]. However, such a definition does not take into consideration the malignant potential of the tumor, which could develop metastasis at a later stage, independently of the presence of metastases at the time of diagnosis or clinical evaluation. In addition, atypical pituitary adenomas and pituitary carcinomas are clinically and histologically similar, so it could be suggested that atypical pituitary adenomas represent tumors with a malignant potential without metastasis [21]. For all of these reasons, the definition of malignant prolactinoma is still a matter of debate in the scientific community $[18,22]$.

The preferential site for metastasis in this type of tumors remains controversial, with reports showing that $57 \%$ of malignant prolactinomas develop systemic metastasis rather than central nervous system metastasis [23] and others showing that central nervous system metastases are more common [17]. In this sense, gallium$68\left({ }^{68} \mathrm{Ga}\right)$-DOTATATE positron emission tomography (PET)/computer tomography (CT) displays a higher resolution and contrast in comparison to ${ }^{18} \mathrm{~F}-\mathrm{FDG}$ PET/ $\mathrm{CT}$ and enhanced magnetic resonance imaging (MRI), at least for identifying cerebral metastases [24]. However, an increased ${ }^{18} \mathrm{~F}$-FDG PET/CT uptake as a marker for tumor aggressiveness, combined with the use of ${ }^{68} \mathrm{Ga}$ -

Malignant Prolactinomas
DOTATATE for somatostatin receptor targeted visualization, seems to represent the method of choice to accurately identify systemic metastases [25]. Malignant prolactinomas exhibit a reported latency between 2 months and 22 years, with an average latency of 4.7 years [23]. The prognosis after a diagnosis of metastatic spread is poor, with a mean survival time of 10 months [17]. Remarkably, both surgery/radiotherapy-naive and DA/TMZ-treated PRL-secreting tumors can present with metastasis and, therefore, the effect of surgery and/or radiotherapy on tumor behavior is difficult to estimate.

Medical treatment with DA is usually used as first-line therapy with the aim of reducing the tumor mass. In contrast, only palliative options remain by the time craniospinal or systemic metastases are evident. Debulking surgery is necessary for symptom relief in the case of compression by a tumor mass. A chemotherapy and/or radiotherapy approach has not been shown to prolong survival. With a lack of other alternatives and according to ESE guidelines, TMZ monotherapy is the first-line chemotherapy after unsuccessful standard therapies [10]. Despite promoting a tumor volume reduction of $47 \%$, TMZ does not seem to prolong the survival time [17].

\section{Aggressive Prolactinomas}

In the case of PRL-secreting pituitary tumors, aggressiveness should be considered in patients with invasive tumors with relevant growth and hormonal overproduction, despite adequate DA therapy, requiring additional treatment such as surgery and radiotherapy and presenting a multirecurrent potential (Table 1). Their prevalence among prolactinomas seems to be low, although it is difficult to assess due to the lack of prospective studies, different definitions of aggressiveness, and the presence of case presentation publication bias. In a multicenter study of 92 patients with cabergoline-resistant prolactinomas, only 4 patients had locally aggressive tumors and 3 patients developed a pituitary carcinoma [26]. Similarly, in an independent study with a cohort of 94 operated prolactinomas, 11 were considered aggressive. There was an equal sex distribution, and 10 patients showed persistence of disease after surgery and 8 showed long-term progression [27]. Furthermore, in a cohort of 102 subjects with aggressive pituitary adenomas, 23 were PRL secreting, with a 3:1 male preponderance. The majority of the patients were surgically treated, with a modest remission rate of $10 \%$ [28].

A particular example of aggressive PRL-secreting tumors is comprised by giant prolactinomas. They are defined as pituitary adenomas with the largest diameter of 
Fig. 1. MRI of a DA-resistant macroprolactinoma in a 12-year-old patient with MEN1. a Before cabergoline treatment (initial PRL level: $923 \mathrm{ng} / \mathrm{mL}$; for conversion to $\mathrm{mU} / \mathrm{L}$, multiply by 21.2 ). b Seven months after cabergoline treatment (PRL level: $893 \mathrm{ng} / \mathrm{m}$ ). At the last follow-up cabergoline was administered daily. Note that, despite no significant tumor volume change under cabergoline treatment, the visual field defect considerably improved in this patient.
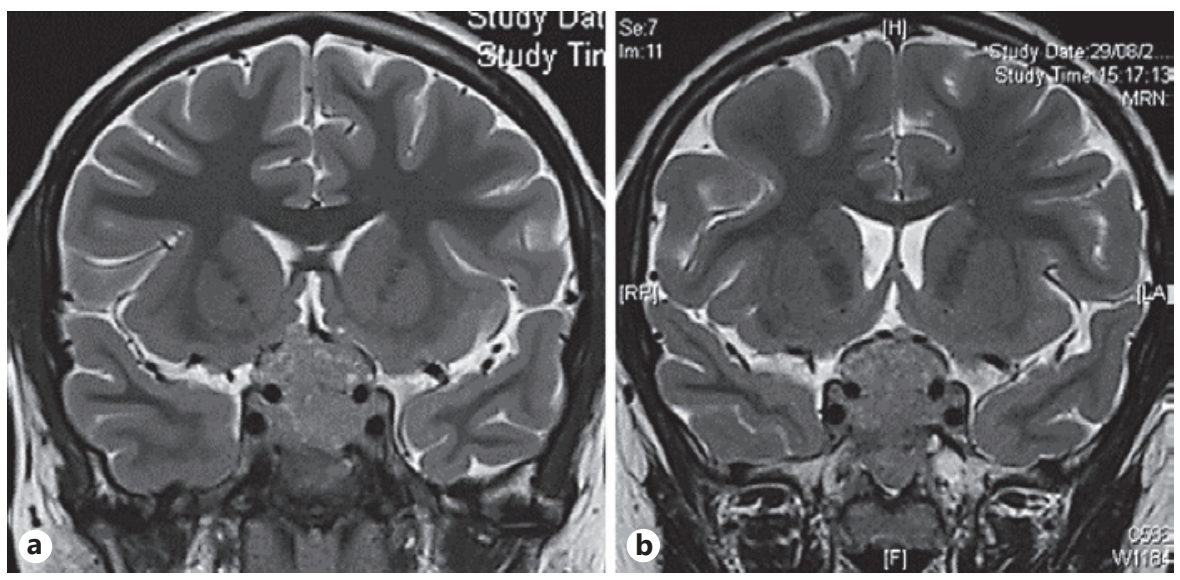

$40 \mathrm{~mm}$ or more in any direction and with: (1) massive extrasellar extension, often into the surrounding intracranial structure; (2) a very high baseline PRL concentration, usually above or equal to $1,000 \mathrm{mg} / \mathrm{L}$ determined using a modern and well-standardized assay; and (3) exclusion of concomitant GH or ACTH secretion $[29,30]$. Giant prolactinomas are rare tumors more frequently found in middle-aged males, with a male-to-female ratio of about 9:1 [29]. However, despite their aggressiveness due to their size and invasiveness, significant tumor shrinkage ( $>30 \%)$ after DA treatment has been observed in 3 out of 4 patients, whereas a lack of PRL normalization on adequate doses has been found only in 1 out 4 patients [29]. A rapid improvement of visual field defects can be observed even in the absence of a significant tumor reduction; however, the risk of CSF leakage and apoplexy is increased in these patients [30].

\section{Resistant-to-Treatment Prolactinomas}

The definition of resistance to DA constitutes a matter of debate and does not really account for the differences between partial and total resistance. However, it is commonly accepted to define resistance to treatment as a failure to normalize serum PRL levels and/or a failure to reduce the tumor size by at least $50 \%$ from the initial volume (Fig. 1) on the maximal conventional doses of DA (i.e., $7.5 \mathrm{mg}$ /day of bromocriptine or $2.0 \mathrm{mg} /$ week of cabergoline) [31]. According to these criteria, the prevalence of DA resistance in patients with prolactinomas is $10-15 \%$ [26].

Among the different molecular explanations for DA resistance, a significant decrease in DRD2 mRNA transcription and/or alterations in the D2 receptor-related signaling pathways play a major role [32-35]. More re- cently, the differential expression of DRD2 isoforms was proposed as a putative molecular mechanism that leads to different responses to DA. In a recent study, patients with surgically resected prolactinomas were divided, based on their response to DA, into the following categories: responder $(n=5)$, resistant $(n=5)$, and secondary resistant to DA $(n=2)$. A significant decrease in the DRD2 long isoform mRNA expression in resistant and secondary resistant tumors as compared to sensitive ones was found [36]. Likewise, the influence of $D R D 2$ gene polymorphisms on the response to DA has been studied in patients with prolactinomas treated with cabergoline, but no correlation has been found $[37,38]$. Recently, a wholeexome sequencing study revealed a lower gene and protein expression of $\mathrm{PR}$ domain zinc finger protein 2 (PRDM2) in bromocriptine-resistant versus responsive prolactinomas [39]. The PRDM2 gene encodes a protein whose major role is to stabilize chromosomal structures, modulating gene expression and ultimately playing a role as a tumor suppressor gene. Moreover, the overexpression of $P R D M 2$ in rat PRL-secreting pituitary tumor MMQ cells led to the upregulation of $D R D 2$ expression and therefore potentiated the inhibitory effect of bromocriptine on PRL secretion [39].

Several other molecular pathways have been implicated in the occurrence of DA resistance in prolactinomas. For instance, the expression of Filamin- $A$, a cytoskeleton protein with scaffolding properties, is downregulated in parallel to DRD2 in human resistant prolactinomas [40]. Moreover, silencing of the Filamin-A expression in human sensitive prolactinomas resulted in a significant decrease in D2 membranous expression and abrogation of the DAinduced inhibition of PRL release and antiproliferative signals. In a reciprocal way, restoration of D2 expression and
60

Neuroendocrinology 2019;109:57-69 DOI: $10.1159 / 000497205$
Olarescu/Perez-Rivas/Gatto/Cuny/ Tichomirowa/Tamagno/Gahete/ 
PRL responsiveness to DA occurred when Filamin- $A$ was overexpressed in resistant prolactinomas [40].

In addition, the TGF- $\beta /$ Smad pathway may be another candidate to explain prolactinoma drug resistance. The TGF- $\beta 1 /$ Smad3 signaling pathway is elevated in resistant prolactinomas with obvious fibrosis, and in vitro experiments have shown that TGF- $\beta 1 / \mathrm{Smad} 3$ pathway-mediated fibrosis is involved in the mechanism of drug resistance [41]. Moreover, a recent study showed that low levels of $P R B 3$ mRNA are observed in resistant prolactinomas and they are associated with a higher risk of tumor recurrence, though the exact role of the PRB3 remains elusive [39].

Finally, although germline PRL receptor $(P R L R) \mathrm{mu}-$ tations are not identified as major causes of sporadic prolactinomas in humans [42], a recent work by Gorvin et al. [43] showed that a rare variant of the PRLR (i.e., Asn492Ile) described in humans with prolactinomas that require surgery could be associated with a higher trend of tumor proliferation and therefore could be a new significant factor sustaining prolactinoma growth, relapse, and ultimately aggressiveness [43]. Therefore, this gain-offunction mutation of $P R L R$, which activates Akt signaling, may represent a novel and possibly clinically useful finding inasmuch as everolimus may constitute a potential effective treatment in these patients, as recently reported in a clinical case [44].

Available treatment approaches for DA-resistant cases could be grouped into medical and nonmedical approaches, as described below. However, in many cases, a multimodal treatment is needed.

\section{Medical Management and Prognosis}

The main medical approach for the treatment of aggressive, invasive tumors that are refractory to first- and second-line therapies is TMZ, an oral chemotherapeutic agent that causes alkylation of guanine to $\mathrm{O}^{6}$-methylguanine, promoting DNA damage by base mismatch repair. Several studies have demonstrated the efficacy of TMZ treatment in aggressive prolactinomas, as well as in other aggressive pituitary tumors. Whitelaw et al. [45] estimated a success rate of $75 \%$ in DA-resistant prolactinomas (15 out of 20 cases), with clinical and biochemical improvement in all cases. However, subsequent analyses have adjusted that success ratio to $50-60 \%$, with most cases being patients in complete or partial remission and about $10-20 \%$ of cases being patients with stable disease $[46,47]$. A recent study reported a cohort of 166 patients with aggressive pituitary tumors and carcinomas treated between 2006 and 2016, including 40 prolactinomas [48]. Most included cases were treated with TMZ as first-line therapy, with a $50 \%$ tumor regression (defined as $\geq 30 \%$ reduction in size) rate in prolactinomas. In this series, complete response (defined as no visible tumor) was achieved in 2 patients (5\%) and disease progression after TMZ was reported in 9 patients (24\%).

According to the scientific evidence, the ESE Clinical Practice Guidelines for the management of aggressive pituitary tumors and carcinomas recommend TMZ as firstline chemotherapy. The standard TMZ regimen consists of cycles of $150-200 \mathrm{mg} / \mathrm{m}^{2}$ for 5 consecutive days every 28 days [10], starting with $150 \mathrm{mg} / \mathrm{m}^{2}$ in the first cycle and increasing to $200 \mathrm{mg} / \mathrm{m}^{2}$. Treatment success evaluation after a 3-month trial allows the identification of TMZ responders $[10,49,50]$. In the case of a good response, the treatment should continue for at least 3 additional cycles, although it can be extended as long as there is a clinical benefit and good tolerance. Hematological toxicity is the most common and dose-limiting adverse effect. Nausea and fatigue have been described at a lower frequency [7]. Importantly, TMZ response is significantly associated with a more extended overall survival $[51,52]$.

A possible mechanism underlying TMZ resistance is the expression of $\mathrm{O}^{6}$-methylguanine-DNA methyltransferase (MGMT). MGMT is an enzyme involved in DNA repair via the removal of nucleotide alkylation caused by TMZ. Indeed, a low MGMT expression or MGMT promoter methylation is related to a better response to TMZ treatment in gliomas and advanced neuroendocrine tumors $[53,54]$. However, MGMT is not a clear predictor of aggressive pituitary tumors. While some studies have shown no significant association [7, 50, 51, 55], other studies have reported a good or partial response to TMZ in patients with a lower MGMT expression $[45,49,56$, 57]. It is important to indicate that most conclusions have been drawn from case reports and small series of patients and stem from different approaches to assess MGMT expression and methylation. In a recent publication by Bengtsson et al. [58] including 17 patients with long-term follow-up after the start of TMZ treatment (30 months), a cut-off value of $10 \%$ MGMT expression allowed a precise and significant stratification of patients into groups of longer and shorter survival ( 83 vs. 26 months, respectively) [58]. However, further studies are needed to precisely determine the predictive value of MGMT.

Unfortunately, there is no solid evidence supporting any other type of medical therapy, which has special relevance for cases of a lack of response or tumor progression after TMZ. Conventional chemotherapeutic agents, 
such as 5-fluorouracil, etoposide, and platinum salt-based schemes, have not demonstrated any consistent effect, although only single cases or small numbers of patients are available in the literature [59-61]. Concomitant treatment with lapatinib and cabergoline was shown to reduce PRL levels in a small pilot trial with 2 patients [62] and is under further investigation. In addition, studies using the first-generation somatostatin analogs lanreotide and octreotide to treat DA-resistant prolactinomas have been inconclusive $[18,63,64]$. However, a recent case report showed promising results with the multireceptor-targeted somatostatin receptor ligand pasireotide. The reported patient was unsuccessfully treated with increasing doses of bromocriptine, several surgeries, and cabergoline and showed a normalization of plasma PRL and disease remission during treatment with pasireotide long-acting release for 6 years [65].

\section{Nonmedical Management and Prognosis}

Surgery is the main nonmedical intervention in prolactinomas patients. Overall, $10-15 \%$ of patients remain DA resistant and require surgery, which can also be considered for patients who are intolerant of medication or have larger tumors prepregnancy [66]. After transphenoidal surgery, biochemical remission with normoprolactinemia is achieved usually in $71-93 \%$ of cases, with a recurrence rate of $18 \%$ in microprolactinomas operated either due to resistance to/intolerance of DA or due to the patient's choice [67]. Remission occurred in 34\% of macroprolactinomas, with a recurrence rate of $23 \%$ [68]. However, it seems that the remission rate is much lower when only cabergolineresistant patients are considered. In the European Multicenter Study of 92 cabergoline-resistant patients, 56 underwent transsphenoidal surgery, and their rate of biochemical control was only $7.8 \%$ without medication and $5.3 \%$ with medication [26]. It is important to note that, nowadays, the morbidity of transsphenoidal surgery is negligible in the hands of experienced pituitary surgeons.

Radiotherapy is usually reserved for: prolactinomas resistant to medical therapy that pose a tumor problem, patients with residual or recurrent tumors after surgery that show a tumor growth potential and threaten the optic chiasma and optic nerves, patients who are disturbed by clinical signs of hyperprolactinemia (e.g., galactorrhea and infertility) and, patients with a high preoperatory risk. As in most hormone-producing pituitary adenomas, tumor control is achieved at a higher rate compared to hormonal control. A recent review reported tumor control ranging from 85 to $100 \%$ and biochemical control ranging from 16 to $47 \%$ at a variable median follow-up of 29-96 months in prolactinomas [69]. The most frequent long-term side effect of radiotherapy is hypopituitarism, followed by an increased risk of malignant brain tumors or meningiomas and a low risk of optic pathway injury [10].

Peptide receptor targeting relies primarily on the presence of sufficiently large quantities of tumor receptors that are able to bind peptide analogs with a high affinity. The radiolabeled peptides can be used both as diagnostic elements and as a means to deliver the radiotracer into the tumor cell, thus increasing the radioactive signal at the target site [70]. In addition to $D R D 2$, prolactinomas express somatostatin receptors (SSTR1-5). Although the immunohistochemistry expression profile may differ from the mRNA expression [71], SSTR1 and SSTR5 seem to be present, while SSTR2 seems to be expressed at low levels, in prolactinomas [72]. However, the knowledge on the SSTR profile in prolactinomas is scarce, with divergent published data. For example, high amounts of SSTR1 mRNA with lower levels of other SSTR have been described [73], whereas in another study SSTR5 mRNA was the dominant receptor subtype in 7 out of 10 tumors [74]. In any case, ${ }^{111}$ In-DTPA-octreotide (OctreoScan) has long been the standard in SST scintigraphy. It binds to SST2 and SST5 and, to a lesser degree, to SST3, while it does not show any affinity to SST1 or SST4. Therefore, this approach has a limited effect on dopamine-resistant prolactinomas, depending on the presence or the absence of these receptor subtypes. A major step forward was the introduction of ${ }^{68} \mathrm{Ga}$-labeled SST agonists for PET, which offer an improved diagnostic sensitivity. ${ }^{68} \mathrm{Ga}$ DOTATATE and ${ }^{68} \mathrm{Ga}$-DOTATOC are ideally suited to identifying eligible patients, whereas ${ }^{177} \mathrm{Lu}$-DOTATATE and ${ }^{90}$ Y-DOTATOC, currently the most frequently used radiopharmaceuticals for peptide receptor radionuclide therapy (PRRT), are rational candidates to treat aggressive prolactinomas [75]. To date, 3 cases of aggressive, resistant-to-treatment prolactinomas and 1 somatomammotroph adenoma have been reportedly treated with PRRT (i.e., 3 patients were treated with ${ }^{111}$ In-DTPA-octreotide and 1 was treated with ${ }^{177} \mathrm{Lu}$-DOTATATE). Two patients responded with remarkable tumor shrinkage and a significant improvement in clinical conditions [76, 77], whereas 2 of them showed tumor progression [77, 78]. In this scenario, a better characterization of the receptor profile may help to predict the clinical response to PRRT. In addition, developing radiolabeled peptide ligands capable of binding D2 or of binding both somatostatin/do-
62

Neuroendocrinology 2019;109:57-69 DOI: $10.1159 / 000497205$
Olarescu/Perez-Rivas/Gatto/Cuny/ Tichomirowa/Tamagno/Gahete/ 
pamine receptors (such as BIM-23A760 - an SST2/SST5/ $\mathrm{D} 2$ receptor agonist, and dopastatin - an SST2/D2 receptor agonist) may represent the new future approach in PRRT of dopamine-resistant prolactinomas.

\section{Aggressive Prolactinomas in Genetic Neuroendocrine Syndromes}

Prolactinomas associated with the presence of genetic syndromes represent only $22-38 \%$ of all pituitary adenomas, whereas their sporadic counterparts exhibit a much higher prevalence. PRL-secreting adenomas with or without associated hyperplasia have been found, in syndromic settings, in multiple endocrine neoplasia type 1 (MEN)1, MEN4, Carney complex, and McCune-Albright syndrome and, in isolated settings, in aryl hydrocarbon receptor interacting protein (AIP) mutation-positive cases, X-linked acrogigantism (XLAG) syndrome due to GPR101 duplications, and AIP- and GPR101-negative familial isolated pituitary adenomas (FIPA) [79].

MEN1 is a genetic disease that predisposes carriers to the development of various endocrine tumors including pituitary adenomas in $30-50 \%$ of patients. Prolactinomas represent the vast majority of secreting adenomas in these patients (up to 73\%) [80], and these tumors seem to be less sensitive to DA and more difficult to treat as compared to their nonmutated counterparts $[81,82]$. Although, there is a lack of molecular explanations to decipher why and how MEN1 mutations lead to a lower sensitivity to DA, a clue could actually lay in the fact that, histologically, MEN1 prolactinomas have a higher probability of being more invasive $[81,83]$. Remarkably, even if the literature presents the evolution of MEN1-related prolactinomas as more aggressive and invasive, with an onset at a younger age and a lower sensitivity to DA [84, 85 ], recent data from more than $90 \%$ of the total Dutch MEN1 population show that MEN-1 prolactinomas responded very well to medical treatment, with just $12 \%$ of cases being resistant; this is similar to the data found for their sporadic counterparts $[80,86]$ and raises the question of publication bias in the former literature.

All XLAG tumors described so far are GH producing, with a majority also secreting PRL (10 out of 12 patients) [87]. Almost all of the cases have a partial or complete resistance to somatostatin analogs while PRL hypersecretion demonstrates variable responsiveness to DA therapy [88]. DA effectively control PRL excess in cases where appropriate doses are used although they do not affect GH hypersecretion [87].

Malignant Prolactinomas
Prolactinomas represent $10 \%$ of all tumor types in the FIPA population and up to $25 \%$ of AIP mutation-positive FIPA families [89]. In an AIP mutation positive cohort, $77 \%$ of the patients in the prolactinoma group were male, contrary to the MEN1 patients where the female preponderance is higher [90]. These patients had large tumors, half of which were not controlled by DA and some of which were difficult to control with multiple surgeries and radiotherapy.

Pituitary tumors in MEN4 patients seem to be less aggressive and, to date, the case of 1 patient with a suspected prolactinoma chronically treated with cabergoline has been published [91]. The relatively small number of cases reported so far with Carney complex or McCune-Albright syndrome and hyperprolactinemia/prolactinomas does not allow drawing of any conclusion with regard to the aggressiveness and the medical response in these patients.

\section{Pathology and Molecular Markers}

Besides clinical behavior and responsiveness to the standard treatment schedule, pathological evaluation represents the cornerstone for the definition of aggressiveness in pituitary tumors, including prolactinomas. Indeed, during the last decade, a number of studies have been focused on the development and validation of the best (clinico)pathological classification able to provide clinicians with a proper definition of tumor characteristics, as well as a prognostic tool for the prediction of postoperative outcomes and long-term tumor recurrence/progression [8-10, 21, 27]. Some of these studies have been specifically implemented in PRL-secreting pituitary tumors [27, 92, 93].

Based on the results generated in a previous study [92], Raverot et al. [27] retrospectively evaluated the clinical, histological, and molecular data of 94 patients treated with surgery for a prolactinoma. In that study, tumors were classified into 3 pathological groups based on their radiological and histological characteristics (i.e., noninvasive, $n=61$; invasive, $n=22$; and aggressive-invasive, $n=11)$. Invasion was evaluated on MRI before surgery and/or histologically (i.e., invasion of the cavernous sinus and the sphenoidal sinus, while suprasellar extension was not included as a criterion), while aggressiveness was defined as the presence of at least 2 out of 3 proliferative markers (Ki-67 index $>1 \%$ in Bouin fixative, number of mitoses $>2$ per 10 high-power fields at $\times 400$ magnification, and positive p53 nuclear detection). Based on the above-described classification, aggressive-invasive prolactinomas were significantly associated with an early

Neuroendocrinology 2019;109:57-69 DOI: $10.1159 / 000497205$ 
negative surgical outcome as well as with the presence of tumor recurrence/progression (mean follow-up 10 years) compared to noninvasive adenomas [27]. Focusing on the characteristics of the aggressive-invasive tumors (11.3\% of the entire cohort), the study showed that all tumors were invasive macroadenomas, with high proliferative markers in all cases (number of mitoses $>10$ in 3 cases, Ki-67 $>5 \%$ in 4 cases, and positive p53 immunoreactivity in all but 1 patient) [27]. In line with the general histological features described for aggressive pituitary tumors, such as the presence of neoangiogenesis and vascular invasion [94], cellular abnormalities and vascular emboli were observed in 2 prolactinomas [27]. The same authors evaluated via qPCR the expression of 9 genes associated with tumor invasion (ADAMTS6, CRMP1, and $D C A M K L 3)$, proliferation (ASK, AURKB, CCNB1, CENPE, and $P T T G$ ), and pituitary differentiation (PITX1) $[27,92]$. Interestingly, 5 genes (ADAMTS6, ASK, CCNB1, $C E N P E$, and $C R M P 1)$ were upregulated in aggressive-invasive tumors, while 7 genes (ADAMTS6, ASK, AURKB, CCNB1, CENPE, CRMP1, and PTTG1) showed a significantly higher expression in tumor samples from patients with recurrence/progression compared to the nonrecurrent group. More recently, activin signaling mediated through ALK7 has been shown to increase the proliferation of prolactinomas, suggesting that ALK7 is an appealing marker for prolactinoma aggressiveness. Interestingly, tumors expressing high ALK7 levels had high Ki67 levels but low PRL expression, indicating a selected cohort of aggressive prolactiomas that are less differentiated and therefore more aggressive [95].

More recently, Trouillas et al. [8] further improved the clinicopathological classification of pituitary tumors described above [27]. In a multicenter case-control study, including 410 pituitary tumors (116 prolactinomas), a grading system ranging from 1a to 3 was settled upon and validated [8]. This grade system takes into account invasiveness ( 1 , noninvasive; 2 , invasive) and proliferation (a, low proliferation rate; $b$, proliferative tumor), with grade 3 defining metastatic tumors (carcinomas). Invasion was defined as previously described by Raverot et al. [27], while proliferation was defined as the presence of at least 2 of the 3 markers including Ki-67, mitotic count, and positive p53. Based on this classification, patients harboring a grade $2 \mathrm{~b}$ prolactinoma (invasive-proliferative) had a significantly lower probability of being disease free 8 years after surgery $(\mathrm{OR}=440.9)$ and a higher risk of tumor recurrence/progression $(\mathrm{OR}=20.14)$ compared to subjects with a grade la prolactinoma [8]. Although the grading system described above is not yet as well established for pituitary le- sions as for gastroenteropancreatic neuroendocrine tumors, Trouillas et al. [8] demonstrated that grade $2 \mathrm{~b}$ prolactinomas showed the most aggressive clinical behavior among the different tumor types. Moreover, 8 out of 410 pituitary tumors were classified as pituitary carcinomas during the study (with no evidence of grade 3 at the first evaluation) and $50 \%$ of them were prolactinomas.

In this sense, a recent commentary of the ESE survey on aggressive pituitary tumors and pituitary carcinomas pointed out that aggressive pituitary tumors are neoplasms with a malignant potential without metastasis, although not all grade $2 \mathrm{~b}$ tumors will show clinically aggressive behavior [21]. This is of particular interest since a tailored treatment ab initio can dramatically change the clinical history and long-term prognosis of aggressive prolactinomas [93].

\section{Preclinical Models of Prolactinomas}

Preclinical in vivo models are fundamental tools in tumor biology research that have been widely used to delineate the development, progression, and behavior of human tumors and may serve for drug evaluation. In general, these preclinical models include genetically engineered mouse models, cell line-based or patient-derived xenografts, and environmentally induced models [96-98]. In the case of pituitary adenomas, and particularly prolactinomas, the majority of the existing preclinical models has been established using genetically engineered mice and, to a lesser extent, environmentally induced rat models.

Among the spectrum of genetically engineered mouse models (Table 2), those generated by the abrogation of $\operatorname{Drd} 2$ and Prlr are especially relevant. In particular, Drd2 knockout mice (Drd2 $\left.{ }^{\text {tm } 1 l o w}\right)$ show chronic hyperprolactinemia and pituitary lactotrope hyperplasia [99], followed by lactotrope tumor formation [100]. Indeed, highly vascularized adenomas develop from 16 months of age, especially in females [99]. This mouse model represents a valuable tool in the study of dopamine-resistant prolactinomas. Prlrdeficient mice $\left(\mathrm{Prlr}^{-/}\right)$also exhibit hyperprolactinemia and tumors associated with increased lactrotrope cell proliferation in both sexes, with a more severe phenotype in females [101]. Indeed, $\mathrm{Prlr}^{-/-}$females develop large secreting prolactinomas with full penetrance after 12 months of age, mimicking human densely granulated aggressive prolactinomas [102]. Prolactinoma development has also been observed in other mouse models with genetic modulation of several prooncogenes or tumor suppressors. Indeed, p19 $9^{\text {Ink4d }}$ (Cdkn2d) knockout mice develop multiple tumor types including PRL-, GH-, and FSH-secreting pituitary tu-
Olarescu/Perez-Rivas/Gatto/Cuny/ Tichomirowa/Tamagno/Gahete/ 
Table 2. Characteristics of the main genetically engineered mouse models of prolactinomas

\begin{tabular}{|c|c|c|c|c|c|}
\hline $\begin{array}{l}\text { Mouse } \\
\text { model }\end{array}$ & $\begin{array}{l}\text { Tumor type } \\
\text { developed }\end{array}$ & $\begin{array}{l}\text { Genetic model } \\
\text { type }\end{array}$ & $\begin{array}{l}\text { Gene altered } \\
\text { (promoter*) }\end{array}$ & Genetic modification & Original reference(s) \\
\hline $\operatorname{Drd} 2^{\text {tmllow }}$ & $\begin{array}{l}\text { Dopamine-resistant prolac- } \\
\text { tinoma }\end{array}$ & $\begin{array}{l}\text { Homozygous } \\
\text { knockout }\end{array}$ & $\operatorname{Drd} 2$ & $\begin{array}{l}\text { Deletion in exon } 8 \text { of the mouse } D r d 2 \text { gene that } \\
\text { encodes the last } 2 \text { transmembrane domains, the } \\
\text { third extracellular loop, and the intracytoplasmic } \\
\text { carboxyl-terminal tail of the receptor }\end{array}$ & 99,100 \\
\hline $\mathrm{Prlr}^{-1-}$ & $\begin{array}{l}\text { Densely granulated aggres- } \\
\text { sive prolactinoma }\end{array}$ & $\begin{array}{l}\text { Homozygous } \\
\text { knockout }\end{array}$ & Prlr & $\begin{array}{l}\text { A } 1.5 \text {-kb fragment containing exon } 5 \text { of Prlr was } \\
\text { replaced with the } \\
\text { similarly sized thymidine kinase-neomycin } \\
\text { resistance gene cassette, leading to an in-frame } \\
\text { stop codon }\end{array}$ & 101,102 \\
\hline$p 19^{-1-}$ & $\begin{array}{l}\text { Multiple tumors including } \\
\text { prolactinomas }\end{array}$ & $\begin{array}{l}\text { Homozygous } \\
\text { knockout }\end{array}$ & $\begin{array}{l}p 19^{\text {Ink4d }} \\
(C d k n 2 d)\end{array}$ & $\begin{array}{l}\text { Deletion of a } 4.6-\mathrm{kb} \text { genomic fragment contain- } \\
\text { ing both exons } 1 \text { and } 2 \text { and encoding all } 166 \\
\text { amino acid residues of the mouse p } 19 \text { protein }\end{array}$ & 103 \\
\hline$H M G A 1-T g$ & $\begin{array}{l}\text { Mixed GH/prolactin- } \\
\text { secreting tumor }\end{array}$ & $\begin{array}{l}\text { Ubiquitous } \\
\text { transgenic }\end{array}$ & $\begin{array}{l}H M G A 1 \\
\left(C m v^{*}\right)\end{array}$ & $\begin{array}{l}\text { Transgenic overexpression of the WT } \\
\text { HMGA1b cDNA under the transcriptional } \\
\text { control of the CMV promoter }\end{array}$ & 104 \\
\hline$H M G A 2-T g$ & $\begin{array}{l}\text { Mixed GH/prolactin- } \\
\text { secreting tumor }\end{array}$ & $\begin{array}{l}\text { Ubiquitous } \\
\text { transgenic }\end{array}$ & $\begin{array}{l}H M G A 2 \\
\left(C m v^{*}\right)\end{array}$ & $\begin{array}{l}\text { Transgenic overexpression of the WT HMGA2 } \\
\text { cDNA under the transcriptional control of the } \\
\text { CMV promoter }\end{array}$ & 105 \\
\hline Galanin-Tg & $\begin{array}{l}\text { Hyperprolactinemia and } \\
\text { pituitary hyperplasia }\end{array}$ & $\begin{array}{l}\text { Cell-specific } \\
\text { transgenic }\end{array}$ & $\begin{array}{l}\text { Galanin } \\
\left(\operatorname{Prl}^{*}\right)\end{array}$ & $\begin{array}{l}\text { Transgenic overexpression of } 4.6 \mathrm{~kb} \text { of the } \\
\text { mouse galanin gene fused to } 2.5 \mathrm{~kb} \text { of the rat } \\
\text { PRL promoter }\end{array}$ & 106 \\
\hline$T F G a-T g$ & Prolactinoma & $\begin{array}{l}\text { Cell-specific } \\
\text { transgenic }\end{array}$ & $\begin{array}{l}\text { TGF- } \alpha \\
\left(\operatorname{Pr} l^{*}\right)\end{array}$ & $\begin{array}{l}\text { Transgenic overexpression of human TGF- } \alpha \\
\text { using the rat PRL promoter }\end{array}$ & 107 \\
\hline$E G F R-T g$ & Prolactinoma & $\begin{array}{l}\text { Cell-specific } \\
\text { transgenic }\end{array}$ & $\begin{array}{l}\text { EGFR } \\
\left(P r l^{*}\right)\end{array}$ & $\begin{array}{l}\text { Transgenic overexpression of human EGFR- } \alpha \\
\text { using the rat PRL promoter }\end{array}$ & 108 \\
\hline EGFR2-Tg & Prolactinoma & $\begin{array}{l}\text { Cell-specific } \\
\text { transgenic }\end{array}$ & $\begin{array}{l}\text { EGFR2 } \\
\left(\text { HER2) }\left(\operatorname{Pr} l^{*}\right)\right.\end{array}$ & $\begin{array}{l}\text { Transgenic overexpression of human EGFR2- } \alpha \\
\text { using the rat PRL promoter }\end{array}$ & 108 \\
\hline
\end{tabular}

mors [103]. Similarly, HMGA1 and HMGA2 transgenic mice develop pituitary tumors that secrete both GH and PRL at approximately $12-16$ months of age [104, 105]. In addition, specific overexpression of certain genes (galanin, TGF- $\alpha$, epidermal growth factor receptor [EGFR], or EGFR2 [HER2]) in the lactotrope cells has also been found to yield to prolactinoma development [106-108]. In contrast to these genetically engineered mouse models, rats have been used as environmentally induced prolactinoma models inasmuch as some rat strains rapidly develop prolactinoma when exposed to estrogen. Some examples are Fischer 344 (F344) and August $\times$ Copenhagen Irish inbred rats in which continuous estrogen treatment induces rapid pituitary growth within a few days and the pituitary is enlarged up to 10 -fold after 8-12 weeks of treatment. PRL overproduction by these estrogen-induced pituitary tumors results in an increase in circulating hyperprolactinemia up to approximately 220 -fold [109-113].
These murine models of prolactinoma contribute greatly to a better understanding of the molecular mechanisms involved in abnormal lactotrope cell proliferation and secretion and to exploration of the pathophysiology of aggressive prolactinomas. Indeed, Prlr knockout mice may constitute a good model of aggressive prolactinomas because tumors express a high mitotic activity. In addition, the absence of tumor shrinkage after 3 months of cabergoline administration suggests that prolactinomas from Prlr knockout mice could serve as a model of the dopamine-resistant subtype [114].

\section{Conclusions}

Prolactinomas are the most prevalent functioning pituitary adenomas and the easiest to treat by endocrinologists, with the majority of cases being responsive to medical treat- 
ment with DA. However, up to $15 \%$ of cases are resistant and locally invasive and depict an aggressive growth pattern. Metastasizing prolactinomas are very rare. Imagistic markers to predict the clinical course of a dopamine-resistant, invasive/aggressive prolactinoma are lacking, whereas the classical pathological markers of aggressiveness (ki67, p53, and mitosis numbers) can be used, but only once the tumor tissue is available. Alteration of several signaling pathways may explain the DA treatment resistance but no medical targets have been available in clinical practice until now. Transsphenoidal surgery is the second-line treatment and the only curative possibility, but its success rate is low due to the local invasiveness of resistant tumors. When surgery fails, and the tumors continue to pose serious problems, TMZ and/or radiation therapy is offered with variable, often poor, clinical responses. PRRT may become more useful in the future assuming that the radiolabeled peptides are directed towards stabile and reliable targets on the tumor cells. In difficult cases, the patients should be managed via a multidisciplinary approach. Preclinical models are useful for our understanding of the pathophysiology of aggressive prolactinomas and may contribute to the discovery of possible medical targets.

\section{Acknowledgement}

M.D.G. is supported by and/or hold the following grants: Junta de Andalucía (CTS-1406, BIO-0139); ISCIII-FIS, cofunded by the European Union (ERDF/ESF, Investing in Your Future) (CP15/00156, PI17/02287); and CIBER (an initiative of the Instituto de Salud Carlos III, Ministerio de Sanidad, Servicios Sociales e Igualdad, Spain).

L.G.P.-R. is supported by the Deutsche Forschungsgemeinschaft (DFG) within the CRC/Transregio 205/1 (The Adrenal: Central Relay in Health and Disease; Project B17).

\section{Disclosure Statement}

The authors have no conflicts of interests to declare.

\section{Author Contributions}

All of the authors substantially contributed to the conception of this review and the drafting of this work. All of the authors have revised this paper critically for important intellectual content and gave their final approval of the version to be published.

\section{References}

1 Daly AF, Rixhon M, Adam C, Dempegioti A, Tichomirowa MA, Beckers A. High prevalence of pituitary adenomas: a cross-sectional study in the province of Liege, Belgium. J Clin Endocrinol Metab. 2006 Dec;91(12):4769-75.

2 Agustsson TT, Baldvinsdottir T, Jonasson JG, Olafsdottir E, Steinthorsdottir V, Sigurdsson $\mathrm{G}$, et al. The epidemiology of pituitary adenomas in Iceland, 1955-2012: a nationwide population-based study. Eur J Endocrinol. 2015 Nov;173(5):655-64.

3 Molitch ME. Diagnosis and Treatment of Pituitary Adenomas: A Review. JAMA. 2017 Feb;317(5):516-24.

4 Mete O, Lopes MB. Overview of the 2017 WHO Classification of Pituitary Tumors. Endocr Pathol. 2017 Sep;28(3):228-43.

5 Meij BP, Lopes MB, Ellegala DB, Alden TD, Laws ER Jr. The long-term significance of microscopic dural invasion in 354 patients with pituitary adenomas treated with transsphenoidal surgery. J Neurosurg. 2002 Feb;96(2): 195-208.

6 Scheithauer BW, Kovacs KT, Laws ER Jr, Randall RV. Pathology of invasive pituitary tumors with special reference to functional classification. J Neurosurg. 1986 Dec;65(6): $733-44$.
7 Raverot G, Castinetti F, Jouanneau E, Morange I, Figarella-Branger D, Dufour $\mathrm{H}$, et al. Pituitary carcinomas and aggressive pituitary tumours: merits and pitfalls of temozolomide treatment. Clin Endocrinol (Oxf). 2012 Jun; 76(6):769-75.

8 Trouillas J, Roy P, Sturm N, Dantony E, CortetRudelli C, Viennet G, et al.; members of HYPOPRONOS. A new prognostic clinicopathological classification of pituitary adenomas: a multicentric case-control study of 410 patients with 8 years post-operative follow-up. Acta Neuropathol. 2013 Jul;126(1):123-35.

9 Asa SL, Casar-Borota O, Chanson P, Delgrange E, Earls P, Ezzat S, et al.; attendees of 14th Meeting of the International Pituitary Pathology Club, Annecy, France, November 2016. From pituitary adenoma to pituitary neuroendocrine tumor (PitNET): an International Pituitary Pathology Club proposal. Endocr Relat Cancer. 2017 Apr;24(4):C5-8.

10 Raverot G, Burman P, McCormack A, Heaney A, Petersenn S, Popovic V, et al.; European Society of Endocrinology. European Society of Endocrinology Clinical Practice Guidelines for the management of aggressive pituitary tumours and carcinomas. Eur J Endocrinol. 2018 Jan;178(1):G1-24.
11 Dworakowska D, Grossman AB. Aggressive and malignant pituitary tumours: state-ofthe-art. Endocr Relat Cancer. 2018 Nov; 25(11):R559-75.

12 Gillam MP, Molitch ME, Lombardi G, Colao A. Advances in the treatment of prolactinomas. Endocr Rev. 2006 Aug;27(5):485-534.

13 Melmed S, Casanueva FF, Hoffman AR, Kleinberg DL, Montori VM, Schlechte JA, et al.; Endocrine Society. Diagnosis and treatment of hyperprolactinemia: an Endocrine Society clinical practice guideline. J Clin Endocrinol Metab. 2011 Feb;96(2):273-88.

14 Bruno OD, Juárez-Allen L, Christiansen SB, Manavela M, Danilowicz K, Vigovich C, et al. Temozolomide therapy for aggressive pituitary tumors: results in a small series of patients from argentina. Int J Endocrinol. 2015; 2015:587893.

15 Vilar L, Abucham J, Albuquerque JL, Araujo LA, Azevedo MF, Boguszewski CL, et al. Controversial issues in the management of hyperprolactinemia and prolactinomas - An overview by the Neuroendocrinology Department of the Brazilian Society of Endocrinology and Metabolism. Arch Endocrinol Metab. 2018 Mar-Apr;62(2):236-63. 
16 Bettencourt-Silva R, Pereira J, Belo S, Magalhães D, Queirós J, Carvalho D. Prolactin-producing pituitary carcinoma, hypopituitarism, and Graves' disease: report of a challenging case and literature review. Front Endocrinol (Lausanne). 2018 Jun;9:312.

17 Yoo F, Kuan EC, Heaney AP, Bergsneider M, Wang MB. Corticotrophic pituitary carcinoma with cervical metastases: case series and literature review. Pituitary. 2018 Jun;21(3): 290-301.

18 Kars M, Roelfsema F, Romijn JA, Pereira AM. Malignant prolactinoma: case report and review of the literature. Eur J Endocrinol. 2006 Oct;155(4):523-34.

19 Phillips J, East HE, French SE, Melcescu E, Hamilton RD, Nicholas WC, et al. What causes a prolactinoma to be aggressive or to become a pituitary carcinoma? Hormones (Athens). 2012 Oct-Dec;11(4):477-82.

20 Balili I, Sullivan S, Mckeever P, Barkan A. Pituitary carcinoma with endolymphatic sac metastasis. Pituitary. 2014 Jun;17(3):210-3.

21 Trouillas J, Burman P, McCormack A, Petersenn S, Popovic V, Dekkers O, et al. Aggressive pituitary tumours and carcinomas: two sides of the same coin? Eur J Endocrinol. 2018 Jun;178(6):C7-9.

22 Vaishya S, Tondon A. Malignant prolactinoma: is metastasis a must? Clinico-pathologic and immunohistochemical study of a case. J Neurosurg Sci. 2004 Mar;48(1):37-41.

23 Pernicone PJ, Scheithauer BW, Sebo TJ, Kovacs KT, Horvath E, Young WF Jr, et al. Pituitary carcinoma: a clinicopathologic study of 15 cases. Cancer. 1997 Feb;79(4):804-12.

24 Xiao J, Zhu Z, Zhong D, Ma W, Wang R. Improvement in diagnosis of metastatic pituitary carcinoma by $68 \mathrm{Ga}$ DOTATATE PET/CT. Clin Nucl Med. 2015 Feb;40(2): e129-31.

25 Garmes HM, Carvalheira JB, Reis F, Queiroz LS, Fabbro MD, Souza VF, et al. Pituitary carcinoma: A case report and discussion of potential value of combined use of Ga-68 DOTATATE and F-18 FDG PET/CT scan to better choose therapy. Surg Neurol Int. 2017 Aug;8(1):162.

26 Vroonen L, Jaffrain-Rea ML, Petrossians P, Tamagno G, Chanson P, Vilar L, et al. Prolactinomas resistant to standard doses of cabergoline: a multicenter study of $92 \mathrm{pa}$ tients. Eur J Endocrinol. 2012 Nov;167(5): 651-62.

27 Raverot G, Wierinckx A, Dantony E, Auger C, Chapas G, Villeneuve L, et al.; HYPOPRONOS. Prognostic factors in prolactin pituitary tumors: clinical, histological, and molecular data from a series of 94 patients with a long postoperative follow-up. J Clin Endocrinol Metab. 2010 Apr;95(4):170816.

28 Ceccato F, Regazzo D, Barbot M, Denaro L, Emanuelli E, Borsetto D, et al. Early recognition of aggressive pituitary adenomas: a single-centre experience. Acta Neurochir (Wien). 2018 Jan;160(1):49-55.
29 Maiter D, Delgrange E. Therapy of endocrine disease: the challenges in managing giant prolactinomas. Eur J Endocrinol. 2014 Jun; 170(6):R213-27.

30 Shimon I, Sosa E, Mendoza V, Greenman Y, Tirosh A, Espinosa E, et al. Giant prolactinomas larger than $60 \mathrm{~mm}$ in size: a cohort of massive and aggressive prolactin-secreting pituitary adenomas. Pituitary. 2016 Aug;19(4): 429-36.

31 Molitch ME. Management of medically refractory prolactinoma. J Neurooncol. 2014 May;117(3):421-8.

32 Pellegrini I, Costa R, Grisoli F, Jaquet P. Abnormal dopamine sensitivity in some human prolactinomas. Horm Res. 1989;31(1-2):19-23.

33 Pellegrini I, Rasolonjanahary R, Gunz G, Bertrand P, Delivet S, Jedynak CP, et al. Resistance to bromocriptine in prolactinomas. J Clin Endocrinol Metab. 1989 Sep;69(3):500-9.

34 Caccavelli L, Feron F, Morange I, Rouer E, Benarous R, Dewailly D, et al. Decreased expression of the two D2 dopamine receptor isoforms in bromocriptine-resistant prolactinomas. Neuroendocrinology. 1994 Sep;60(3):314-22.

35 Caccavelli L, Morange-Ramos I, Kordon C, Jaquet $\mathrm{P}$, Enjalbert A. Alteration of $\mathrm{G}$ alpha subunits mRNA levels in bromocriptine resistant prolactinomas. J Neuroendocrinol. 1996 Oct;8(10):737-46.

36 Shimazu S, Shimatsu A, Yamada S, Inoshita $\mathrm{N}$, Nagamura $\mathrm{Y}$, Usui $\mathrm{T}$, et al. Resistance to dopamine agonists in prolactinoma is correlated with reduction of dopamine D2 receptor long isoform mRNA levels. Eur J Endocrinol. 2012 Mar;166(3):383-90.

37 Bueno C, Trarbach EB, Bronstein MD, Glezer A. Cabergoline and prolactinomas: lack of association between DRD2 polymorphisms and response to treatment. Pituitary. 2017 Jun; 20(3):295-300.

38 Filopanti M, Barbieri AM, Angioni AR, Colao A, Gasco V, Grottoli S, et al. Dopamine D2 receptor gene polymorphisms and response to cabergoline therapy in patients with prolactin-secreting pituitary adenomas. Pharmacogenomics J. 2008 Oct;8(5):357-63.

39 Gao H, Wang F, Lan X, Li C, Feng J, Bai J, et al. Lower PRDM2 expression is associated with dopamine-agonist resistance and tumor recurrence in prolactinomas. BMC Cancer. 2015 Apr;15(1):272.

40 Peverelli E, Mantovani G, Vitali E, Elli FM, Olgiati L, Ferrero S, et al. Filamin-A is essential for dopamine $\mathrm{d} 2$ receptor expression and signaling in tumorous lactotrophs. J Clin Endocrinol Metab. 2012 Mar;97(3):967-77.

41 Hu B, Mao Z, Jiang X, He D, Wang Z, Wang $X$, et al. Role of TGF- $\beta 1 /$ Smad3-mediated fibrosis in drug resistance mechanism of prolactinoma. Brain Res. 2018 Nov; 1698: 204-12.

42 Bernard V, Bouilly J, Beau I, Broutin I, Chanson P, Young J, et al. Germline Prolactin Receptor Mutation Is Not a Major Cause of Sporadic Prolactinoma in Humans. Neuroendocrinology. 2016;103(6):738-45.
43 Gorvin CM, Newey PJ, Rogers A, Stokes V, Neville MJ, Lines KE, et al. Association of prolactin receptor (PRLR) variants with prolactinomas. Hum Mol Genet. 2018 Nov. https:// doi.org/10.1093/hmg/ddy396.

44 Zhang D, Way JS, Zhang X, Sergey M, Bergsneider M, Wang MB, et al. Effect of Everolimus in Treatment of Aggressive Prolactin-Secreting Pituitary Adenomas. J Clin Endocrinol Metab. 2019 Jan. https://doi.org/10.1210/ jc.2018-02461.

45 Whitelaw BC, Dworakowska D, Thomas NW, Barazi S, Riordan-Eva P, King AP, et al. Temozolomide in the management of dopamine agonist-resistant prolactinomas. Clin Endocrinol (Oxf). 2012 Jun;76(6):877-86.

46 Chen C, Yin S, Zhang S, Wang M, Hu Y, Zhou $\mathrm{P}$, et al. Treatment of aggressive prolactinoma with temozolomide: A case report and review of literature up to date. Medicine (Baltimore). 2017 Nov;96(47):e8733.

47 Halevy C, Whitelaw BC. How effective is temozolomide for treating pituitary tumours and when should it be used? Pituitary. 2017 Apr;20(2):261-6.

48 McCormack A, Dekkers OM, Petersenn S, Popovic V, Trouillas J, Raverot G, et al.; ESE survey collaborators. Treatment of aggressive pituitary tumours and carcinomas: results of a European Society of Endocrinology (ESE) survey 2016. Eur J Endocrinol. 2018 Mar; 178(3):265-76.

49 Bengtsson D, Schrøder HD, Andersen M, Maiter D, Berinder K, Feldt Rasmussen U, et al. Long-term outcome and MGMT as a predictive marker in 24 patients with atypical pituitary adenomas and pituitary carcinomas given treatment with temozolomide. J Clin Endocrinol Metab. 2015 Apr;100(4):1689-98.

50 Raverot G, Sturm N, de Fraipont F, Muller M, Salenave S, Caron P, et al. Temozolomide treatment in aggressive pituitary tumors and pituitary carcinomas: a French multicenter experience. J Clin Endocrinol Metab. 2010 Oct;95(10):4592-9.

51 Lasolle H, Cortet C, Castinetti F, Cloix L, Caron $\mathrm{P}$, Delemer B, et al. Temozolomide treatment can improve overall survival in aggressive pituitary tumors and pituitary carcinomas. Eur J Endocrinol. 2017 Jun;176(6):769-77.

52 Losa M, Bogazzi F, Cannavo S, Ceccato F, Curtò L, De Marinis L, et al. Temozolomide therapy in patients with aggressive pituitary adenomas or carcinomas. J Neurooncol. 2016 Feb;126(3):519-25.

53 Campana D, Walter T, Pusceddu S, Gelsomino F, Graillot E, Prinzi N, et al. Correlation between MGMT promoter methylation and response to temozolomide-based therapy in neuroendocrine neoplasms: an observational retrospective multicenter study. Endocrine. 2018 Jun;60(3):490-8.

54 Hegi ME, Diserens AC, Gorlia T, Hamou MF, de Tribolet N, Weller M, et al. MGMT gene silencing and benefit from temozolomide in glioblastoma. N Engl J Med. 2005 Mar; 352(10):997-1003. 
55 Bush ZM, Longtine JA, Cunningham T, Schiff D, Jane JA Jr, Vance ML, et al. Temozolomide treatment for aggressive pituitary tumors: correlation of clinical outcome with $\mathrm{O}(6)$ methylguanine methyltransferase (MGMT) promoter methylation and expression. J Clin Endocrinol Metab. 2010 Nov;95(11):E28090.

56 Hagen C, Schroeder HD, Hansen S, Hagen C, Andersen M. Temozolomide treatment of a pituitary carcinoma and two pituitary macroadenomas resistant to conventional therapy. Eur J Endocrinol. 2009 Oct;161(4):631-7.

57 Almalki MH, Aljoaib NN, Alotaibi MJ, Aldabas BS, Wahedi TS, Ahmad MM, et al. Temozolomide therapy for resistant prolactin-secreting pituitary adenomas and carcinomas: a systematic review. Hormones (Athens). 2017 Apr;16(2):139-49.

58 Bengtsson D, Schrøder HD, Berinder K, Maiter D, Hoybye C, Ragnarsson O, et al. Tumoral MGMT content predicts survival in patients with aggressive pituitary tumors and pituitary carcinomas given treatment with temozolomide. Endocrine. 2018 Dec;62(3): 737-9.

59 Hurel SJ, Harris PE, McNicol AM, Foster S, Kelly WF, Baylis PH. Metastatic prolactinoma: effect of octreotide, cabergoline, carboplatin and etoposide; immunocytochemical analysis of proto-oncogene expression. J Clin Endocrinol Metab. 1997 Sep;82(9):2962-5.

60 Kaltsas GA, Mukherjee JJ, Plowman PN, Monson JP, Grossman AB, Besser GM. The role of cytotoxic chemotherapy in the management of aggressive and malignant pituitary tumors. J Clin Endocrinol Metab. 1998 Dec;83(12):4233-8

61 Walker JD, Grossman A, Anderson JV, Ur E, Trainer PJ, Benn J, et al. Malignant prolactinoma with extracranial metastases: a report of three cases. Clin Endocrinol (Oxf). 1993 Apr; 38(4):411-9.

62 Cooper O, Mamelak A, Bannykh S, Carmichael J, Bonert V, Lim S, et al. Prolactinoma ErbB receptor expression and targeted therapy for aggressive tumors. Endocrine. 2014 Jun;46(2):318-27.

63 Fusco A, Lugli F, Sacco E, Tilaro L, Bianchi A, Angelini F, et al. Efficacy of the combined cabergoline and octreotide treatment in a case of a dopamine-agonist resistant macroprolactinoma. Pituitary. 2011 Dec;14(4):351-7.

64 Sosa-Eroza E, Espinosa E, Ramírez-Rentería C, Mendoza V, Arreola R, Mercado M. Treatment of multiresistant prolactinomas with a combination of cabergoline and octreotide LAR. Endocrine. 2018 Aug;61(2):343-8.

65 Lasolle H, Vasiljevic A, Borson-Chazot F, Raverot G. Pasireotide: a potential therapeutic alternative for resistant prolactinoma. Ann Endocrinol (Paris). DOI: 10.1016/j.ando. 2018.07.013.

66 Langlois F, McCartney S, Fleseriu M. Recent Progress in the Medical Therapy of Pituitary Tumors. Endocrinol Metab (Seoul). 2017 Jun; 32(2):162-70
67 Tampourlou M, Trifanescu R, Paluzzi A, Ahmed SK, Karavitaki N. THERAPY OF ENDOCRINE DISEASE: Surgery in microprolactinomas: effectiveness and risks based on contemporary literature. Eur J Endocrinol. 2016 Sep;175(3):R89-96.

68 Glezer A, Bronstein MD. Prolactinomas. Endocrinol Metab Clin North Am. 2015 Mar; 44(1):71-8.

69 Minniti G, Clarke E, Scaringi C, Enrici RM. Stereotactic radiotherapy and radiosurgery for non-functioning and secreting pituitary adenomas. Rep Pract Oncol Radiother. 2016 Jul-Aug;21(4):370-8.

70 Reubi JC. Peptide receptors as molecular targets for cancer diagnosis and therapy. Endocr Rev. 2003 Aug;24(4):389-427.

71 Körner M, Waser B, Christ E, Beck J, Reubi JC. A Critical Evaluation of sst 3 and sst5 Immunohistochemistry in Human Pituitary Adenomas. Neuroendocrinology. 2018;106(2):116-27.

72 Moraes AB, Silva CM, Vieira Neto L, Gadelha MR. Giant prolactinomas: the therapeutic approach. Clin Endocrinol (Oxf). 2013 Oct; 79(4):447-56

73 Ibáñez-Costa A, Rivero-Cortés E, VázquezBorrego MC, Gahete MD, Jiménez-Reina L, Venegas-Moreno E, et al. Octreotide and pasireotide (dis)similarly inhibit pituitary tumor cells in vitro. J Endocrinol. 2016 Nov; 231(2):135-45.

74 Jaquet P, Ouafik L, Saveanu A, Gunz G, Fina F, Dufour H, et al. Quantitative and functional expression of somatostatin receptor subtypes in human prolactinomas. J Clin Endocrinol Metab. 1999 Sep;84(9):3268-76.

75 Pauwels E, Cleeren F, Bormans G, Deroose $\mathrm{CM}$. Somatostatin receptor PET ligands - the next generation for clinical practice. Am J Nucl Med Mol Imaging. 2018 Oct;8(5):311-31.

76 Baldari S, Ferraù F, Alafaci C, Herberg A, Granata F, Militano V, et al. First demonstration of the effectiveness of peptide receptor radionuclide therapy (PRRT) with 111In-DTPAoctreotide in a giant PRL-secreting pituitary adenoma resistant to conventional treatment. Pituitary. 2012 Dec;15(S1 Suppl 1):S57-60.

77 Priola SM, Esposito F, Cannavò S, Conti A, Abbritti RV, Barresi V, et al. Aggressive pituitary adenomas: the dark side of the moon. World Neurosurg. 2017 Jan;97:140-55.

78 Maclean J, Aldridge M, Bomanji J, Short S, Fersht N. Peptide receptor radionuclide therapy for aggressive atypical pituitary adenoma/carcinoma: variable clinical response in preliminary evaluation. Pituitary. 2014 Dec;17(6):530-8.

79 Iacovazzo D, Korbonits M. X-linked acrogigantism. In: Adam MP, Ardinger HH, Pagon RA, et al., editors. GeneReviews. Seattle: University of Washington; 1993.

80 de Laat JM, Dekkers OM, Pieterman CR, Kluijfhout WP, Hermus AR, Pereira AM, et al. Long-Term Natural Course of Pituitary Tumors in Patients With MEN1: Results From the DutchMEN1 Study Group (DMSG). J Clin Endocrinol Metab. 2015 Sep;100(9): 3288-96.
81 Vergès $B$, Boureille $F$, Goudet $P$, Murat $A$, Beckers A, Sassolas G, et al. Pituitary disease in MEN type 1 (MEN1): data from the FranceBelgium MEN1 multicenter study. J Clin Endocrinol Metab. 2002 Feb;87(2):457-65.

82 Salenave S, Ancelle D, Bahougne T, Raverot G, Kamenický P, Bouligand J, et al. Macroprolactinomas in children and adolescents: factors associated with the response to treatment in 77 patients. J Clin Endocrinol Metab. 2015 Mar; 100(3):1177-86.

83 Trouillas J, Labat-Moleur F, Sturm N, Kujas M, Heymann MF, Figarella-Branger D, et al.; Groupe d'études des Tumeurs Endocrines. Pituitary tumors and hyperplasia in multiple endocrine neoplasia type 1 syndrome (MEN1): a case-control study in a series of 77 patients versus 2509 non-MEN1 patients. Am J Surg Pathol. 2008 Apr;32(4):534-43.

84 Subasinghe CJ, Somasundaram N, Sivatharshya P, Ranasinghe LD, Korbonits M. Giant prolactinoma of young onset: a clue to diagnosis of MEN-1 syndrome. Case Rep Endocrinol. 2018 Aug;2018:2875074.

85 Delemer B. MEN1 and pituitary adenomas. Ann Endocrinol (Paris). 2012 Apr;73(2):5961.

86 van Leeuwaarde RS, de Laat JM, Pieterman CR, Dreijerink K, Vriens MR, Valk GD. The future: medical advances in MEN1 therapeutic approaches and management strategies. Endocr Relat Cancer. 2017 Oct;24(10):T179_ 93.

87 Iacovazzo D, Caswell R, Bunce B, Jose S, Yuan B, Hernández-Ramírez LC, et al. Germline or somatic GPR101 duplication leads to Xlinked acrogigantism: a clinico-pathological and genetic study. Acta Neuropathol Commun. 2016 Jun;4(1):56.

88 Beckers A, Rostomyan L, Potorac I, Beckers P, Daly AF. X-LAG: how did they grow so tall? Ann Endocrinol (Paris). 2017 Jun;78(2):1316.

89 Stiles CE, Korbonits M. Familial isolated pituitary adenoma. In: De Groot LJ, Chrousos G, Dungan K, et al., editors. Endotext. Dartmouth: MDText.com; 2000.

90 Daly AF, Tichomirowa MA, Petrossians P, Heliövaara E, Jaffrain-Rea ML, Barlier A, et al. Clinical characteristics and therapeutic responses in patients with germ-line AIP mutations and pituitary adenomas: an international collaborative study. J Clin Endocrinol Metab. 2010 Nov;95(11):E373-83.

91 Tichomirowa MA, Lee M, Barlier A, Daly AF, Marinoni I, Jaffrain-Rea ML, et al. Cyclin-dependent kinase inhibitor 1B (CD$\mathrm{KN} 1 \mathrm{~B})$ gene variants in AIP mutation-negative familial isolated pituitary adenoma kindreds. Endocr Relat Cancer. 2012 May;19(3): $233-41$.

92 Wierinckx A, Auger C, Devauchelle P, Reynaud A, Chevallier P, Jan M, et al. A diagnostic marker set for invasion, proliferation, and aggressiveness of prolactin pituitary tumors. Endocr Relat Cancer. 2007 Sep;14(3):887900 
93 Zemmoura I, Wierinckx A, Vasiljevic A, Jan M, Trouillas J, François P. Aggressive and malignant prolactin pituitary tumors: pathological diagnosis and patient management. Pituitary. 2013 Dec;16(4):515-22.

94 Raverot G, Jouanneau E, Trouillas J. Management of endocrine disease: clinicopathological classification and molecular markers of pituitary tumours for personalized therapeutic strategies. Eur J Endocrinol. 2014 Mar;170(4):R121-32.

95 Principe M, Chanal M, Karam V, Wierinckx A, Mikaélian I, Gadet R, et al. ALK7 expression in prolactinoma is associated with reduced prolactin and increased proliferation. Endocr Relat Cancer. 2018 Sep;25(9):795806.

96 Day CP, Merlino G, Van Dyke T. Preclinical mouse cancer models: a maze of opportunities and challenges. Cell. 2015 Sep;163(1): 39-53.

97 Gengenbacher N, Singhal M, Augustin HG. Preclinical mouse solid tumour models: status quo, challenges and perspectives. Nat Rev Cancer. 2017 Dec;17(12):751-65.

98 Kersten K, de Visser KE, van Miltenburg $\mathrm{MH}$, Jonkers J. Genetically engineered mouse models in oncology research and cancer medicine. EMBO Mol Med. 2017 Feb; 9(2):137-53.

99 Kelly MA, Rubinstein M, Asa SL, Zhang G, Saez C, Bunzow JR, et al. Pituitary lactotroph hyperplasia and chronic hyperprolactinemia in dopamine D2 receptor-deficient mice. Neuron. 1997 Jul;19(1):103-13.

100 Asa SL, Kelly MA, Grandy DK, Low MJ. Pituitary lactotroph adenomas develop after prolonged lactotroph hyperplasia in dopamine D2 receptor-deficient mice. Endocrinology. 1999 Nov;140(11):5348-55.
101 Ormandy CJ, Camus A, Barra J, Damotte D, Lucas B, Buteau $\mathrm{H}$, et al. Null mutation of the prolactin receptor gene produces multiple reproductive defects in the mouse. Genes Dev. 1997 Jan;11(2):167-78.

102 Schuff KG, Hentges ST, Kelly MA, Binart N, Kelly PA, Iuvone PM, et al. Lack of prolactin receptor signaling in mice results in lactotroph proliferation and prolactinomas by dopamine-dependent and -independent mechanisms. J Clin Invest. 2002 Oct;110(7):973-81.

103 Bai F, Chan HL, Smith MD, Kiyokawa H, Pei $\mathrm{XH}$. p19Ink4d is a tumor suppressor and controls pituitary anterior lobe cell proliferation. Mol Cell Biol. 2014 Jun;34(12): 2121-34.

104 Fedele M, Pentimalli F, Baldassarre G, Battista S, Klein-Szanto AJ, Kenyon L, et al. Transgenic mice overexpressing the wildtype form of the HMGA1 gene develop mixed growth hormone/prolactin cell pituitary adenomas and natural killer cell lymphomas. Oncogene. 2005 May;24(21):3427-35.

105 Fedele M, Battista S, Kenyon L, Baldassarre G, Fidanza V, Klein-Szanto AJ, et al. Overexpression of the HMGA2 gene in transgenic mice leads to the onset of pituitary adenomas. Oncogene. 2002 May;21(20):3190-8.

106 Cai A, Hayes JD, Patel N, Hyde JF. Targeted overexpression of galanin in lactotrophs of transgenic mice induces hyperprolactinemia and pituitary hyperplasia. Endocrinology. 1999 Nov;140(11):4955-64.

107 McAndrew J, Paterson AJ, Asa SL, McCarthy KJ, Kudlow JE. Targeting of transforming growth factor-alpha expression to pituitary lactotrophs in transgenic mice results in selective lactotroph proliferation and adenomas. Endocrinology. 1995 Oct;136(10): 4479-88.
108 Liu X, Kano M, Araki T, Cooper O, Fukuoka $\mathrm{H}$, Tone $\mathrm{Y}$, et al. ErbB receptor-driven prolactinomas respond to targeted lapatinib treatment in female transgenic mice. Endocrinology. 2015 Jan;156(1):71-9.

109 Spady TJ, Harvell DM, Lemus-Wilson A, Strecker TE, Pennington KL, Vander Woude EA, et al. Modulation of estrogen action in the rat pituitary and mammary glands by dietary energy consumption. J Nutr. 1999;129: 587S-90S.

110 Lloyd RV. Estrogen-induced hyperplasia and neoplasia in the rat anterior pituitary gland. An immunohistochemical study. Am J Pathol. 1983 Nov;113(2):198-206.

111 Kansra S, Yamagata S, Sneade L, Foster L, Ben-Jonathan N. Differential effects of estrogen receptor antagonists on pituitary lactotroph proliferation and prolactin release. Mol Cell Endocrinol. 2005 Jul;239(1-2):2736.

112 Cao L, Gao H, Gui S, Bai G, Lu R, Wang F, et al. Effects of the estrogen receptor antagonist fulvestrant on F344 rat prolactinoma models. J Neurooncol. 2014 Feb;116(3): 523-31.

113 Dennison KL, Samanas NB, Harenda QE, Hickman MP, Seiler NL, Ding L, et al. Development and characterization of a novel rat model of estrogen-induced mammary cancer. Endocr Relat Cancer. 2015 Apr;22(2): 239-48.

114 Bernard V, Villa C, Auguste A, Lamothe S, Guillou A, Martin A, et al. Natural and molecular history of prolactinoma: insights from a Prlr-/- mouse model. Oncotarget. 2017 Dec;9(5):6144-55. 